\title{
Biodegradability Enhancement of Mature Landfill Leachate Using Fenton Process under Different COD Loading Factors
}

\author{
Anna R. Bernardo-Bricker • Shrawan K. Singh • \\ Alam G. Trovó • Walter Z. Tang • Georgio Tachiev
}

Received: 31 December 2013 / Accepted: 21 March 2014 /Published online: 29 April 2014

(C) Springer International Publishing Switzerland 2014

\begin{abstract}
The Fenton process is evaluated as a treatment method to reduce the total organic carbon (TOC) and increase biodegradability of the organic substrate in a mature landfill leachate. Biodegradability was quantified in terms of the ratios between biochemical oxygen demand after 5 days $\left(\mathrm{BOD}_{5}\right)$ to chemical oxygen demand (COD) (after different Fenton reaction times), and $\mathrm{BOD}_{5}$ (after different Fenton reaction times) to initial $\mathrm{BOD}_{5}$ (original leachate sample), termed as $\mathrm{BOD}_{5,0}$, respectively. An increased TOC removal and improved $\mathrm{BOD}_{5} / \mathrm{COD}$ ratios were observed following the $\mathrm{pH}$ sequence of $3.5>6.0>2.0$. The maximum TOC removal of $61 \%$ and the highest $\mathrm{BOD}_{5} / \mathrm{COD}$ ratio from 0.11 to 0.37 were observed at $\mathrm{pH}$ 3.5. To quantify biodegradability enhancement at different $\mathrm{COD}$ loading factors $\left(\mathrm{L}_{\mathrm{COD}}\right)$ by the Fenton process, the $\mathrm{H}_{2} \mathrm{O}_{2} / \mathrm{Fe}^{2+}$ ratio was fixed at $1.8(w / w)$ and $\mathrm{L}_{\mathrm{COD}}$ ranged from 0.22 to 1.19. Experimental results showed that higher TOC removal and biodegradability enhancement were obtained at lower $\mathrm{L}_{\mathrm{COD}}$. Quantitatively, two linear regression equations between $\mathrm{L}_{\mathrm{COD}}$ and biodegradability (in terms of $\mathrm{BOD}_{5} / \mathrm{COD}$ and $\mathrm{BOD}_{5} / \mathrm{BOD}_{5,0}$ ) were established, as: $\mathrm{BOD}_{5} / \mathrm{COD}=0.57-0.38 \mathrm{~L}_{\mathrm{COD}}$ and $\mathrm{BOD}_{5} / \mathrm{BOD}_{5,0}=1.40-0.40 \mathrm{~L}_{\mathrm{COD}}$ with correlation coefficients $\left(R^{2}\right)$ of 0.87 and 0.51 , respectively. The experimental work described here, demonstrated
\end{abstract}

A. R. Bernardo-Bricker · S. K. Singh • W. Z. Tang $(\bowtie)$

Department of Civil and Environmental Engineering, Florida International University, Miami, FL 33174, USA

e-mail: tangz@fiu.edu

A. R. Bernardo-Bricker

e-mail: abernard@fiu.edu

S. K. Singh

e-mail: shrawan.singh@gmail.com

A. G. Trovó

Instituto de Química, Universidade Federal de Uberlândia, Uberlândia, MG 38400-902, Brasil

e-mail: alamtrovo@iqufu.ufu.br

G. Tachiev

Applied Research Center, Florida International University, 10555 West Flagler Street, Miami, FL 33174, USA

e-mail: georgio.tachiev@fiu.edu 
that the Fenton process can be used as an effective pre-treatment strategy to increase leachate biodegradability within a short reaction time from 1 to $5 \mathrm{~min}$.

Keywords Leachate biodegradability enhancement · Fenton process · COD loading · $\mathrm{BOD}_{5} / \mathrm{COD}$ ratio $\cdot \mathrm{BOD}_{5} / \mathrm{BOD}_{5,0}$ ratio

\section{Introduction}

Landfill leachate typically contains high concentrations of dissolved organic matter (OM) and inorganic compounds such as ammonia. Therefore, it may impose a considerable risk of impairing the water quality of the receiving aquatic systems if leachate was discharged to either surface or groundwater without any treatment (EPA 1988). To prevent contamination of aquatic systems, conventional biological wastewater treatment technologies are effective when organic compounds in wastewater are biodegradable. However, biodegradability of leachate varies greatly as function of waste composition and age. Typically, biodegradable OM is dominant in leachate composition during the first few years of landfill operation. As the landfill ages, the biodegradable portion is depleted and the organic load is enriched in recalcitrant organic compounds, such as humic and fulvic OM with heavy metals and toxic organic pollutants (de Morais and Zamora 2005; Batarseh et al. 2007; Naumczysky et al. 2012). Advanced oxidation processes (AOPs) are among the alternative treatment technologies that have been proposed for effective treatment of leachate at this stage (Wang et al. 2003; Deng and Englehardt 2006). Among the AOPs, great attention has been given to Fenton process (Zhang et al. 2005; Umar et al. 2010; Cortez et al. 2011). During Fenton oxidation, hydroxyl radical is generated in a homogeneous medium by mixing of hydrogen peroxide with ferrous iron at room temperature in the dark, as follows (Eq. 1):

$$
\mathrm{Fe}^{2+}+\mathrm{H}_{2} \mathrm{O}_{2} \rightarrow \mathrm{Fe}^{3+}+{ }^{\circ} \mathrm{OH}+\mathrm{HO}^{-} \quad \mathrm{k}=76 \mathrm{M}^{-1} \cdot \mathrm{s}^{-1}
$$

The theoretical amount of $\mathrm{H}_{2} \mathrm{O}_{2}$ required for oxidation on a mass-basis is equal to 2.125 times the mass of molecular oxygen (Eq. 2); that is, 2.125 times the initial chemical oxygen demand (COD) (Gernjak et al. 2003).

$$
2 \mathrm{H}_{2} \mathrm{O}_{2} \rightarrow 2 \mathrm{H}_{2} \mathrm{O}+\mathrm{O}_{2}
$$

At a much slower process, the ferric ions generated in Eq. (2) will be reduced to ferrous ions by $\mathrm{H}_{2} \mathrm{O}_{2}$ :

$$
\mathrm{Fe}^{3+}+\mathrm{H}_{2} \mathrm{O}_{2} \rightarrow \mathrm{Fe}^{2+}+\mathrm{HO}_{2}{ }^{\cdot}+\mathrm{H}^{+} \mathrm{k}=10^{-3}-10^{-2} \mathrm{M}^{-1} \cdot \mathrm{s}^{-1}
$$

The Fenton process offers many advantages. For example, chemical reagents used are abundant, inexpensive and environmentally benign. In addition, the Fenton process is a homogeneous catalytic process in nature without mass transfer limitation. Fenton reaction requires low pH values in the range from 2.5 to 3.5 (Pignatello 1992; Nogueira and Guimarães 2000). As a result, two steps are necessary for effective oxidation of organic pollutants: (1) before the Fenton process, the $\mathrm{pH}$ has to be adjusted to 2.5-3.5; and (2) after the Fenton process, lime has to be added to raise $\mathrm{pH}$ to the neutral value so that the treated waters could be discharged to sewers or surface waters.

Since the rate constant of Eq. (3) is three orders of magnitude smaller than that of Eq. (1), ferrous ions are usually regenerated slowly through Eq. (3). Therefore, a high initial amount of 
$\mathrm{Fe}^{2+}$ is necessary to obtain high degradation efficiency. As a result, a large amount of ferric hydroxide sludge will be generated. To determine the optimal dose of $\mathrm{H}_{2} \mathrm{O}_{2}$ and $\mathrm{Fe}^{2+}$, laboratory experimental work is usually carried out to optimize chemical reagents for each specific leachate. In this paper, the COD loading factor $\left(\mathrm{L}_{\mathrm{COD}}\right)$ is used as a key variable during the quantification of biodegradability enhancement of leachate by Fenton process. Since the $\mathrm{H}_{2} \mathrm{O}_{2}$ demand is only determined by the soluble COD of leachate during Fenton oxidation at pH 3.5 (Singh and Tang 2013), quantitative correlations between the ratios of $\mathrm{BOD}_{5} / \mathrm{COD}$ or $\mathrm{BOD}_{5} / \mathrm{BOD}_{5,0}$ with $\mathrm{L}_{\mathrm{COD}}$ could be considered as universally applicable for biodegradability enhancement of mature leachate by the Fenton process.

The Fenton process was investigated as an effective and inexpensive pre-treatment for biodegradability enhancement of leachate. Many experimental works have showed that the toxic and recalcitrant compounds could be degraded by the Fenton process to low weight organic compounds, which generally show higher biodegradability (Lopez et al. 2004; Goi et al. 2010; Gotvajn et al. 2011; Nurisepehr et al. 2012; Vilar et al. 2013). Although many applications of the Fenton processes to improve landfill leachate biodegradability have been reported (e.g., Goi et al. 2010; Gotvajn et al. 2011; Nurisepehr et al. 2012; Vilar et al. 2013; Singh et al. 2013), these previous studies did not report the role of $\mathrm{pH}$ on biodegradability when the Fenton process was evaluated as an alternative to the pre-treatment of mature landfill leachate to improve the biodegradability. In addition, no quantitative relationship between the biodegradability enhancement and the mass ratio of COD present in leachate to available oxygen in $\mathrm{H}_{2} \mathrm{O}_{2}$, referred to as COD loading factor $\left(\mathrm{L}_{\mathrm{COD}}\right)$, was ever reported. Therefore, the objectives of this study were to evaluate the biodegradability enhancement in terms of either $\mathrm{BOD}_{5} / \mathrm{COD}$ or $\mathrm{BOD}_{5} / \mathrm{BOD}_{5,0}$ ratios under different $\mathrm{L}_{\mathrm{COD}}$ values. The $\mathrm{BOD}_{5} / \mathrm{COD}$ ratio reflects biodegradability enhancement of non-biodegradable $\mathrm{OM}$ to biodegradable $\mathrm{OM}$ in leachate, while the $\mathrm{BOD}_{5} / \mathrm{BOD}_{5,0}$ ratio reflects biodegradability enhancement after Fenton process compared to its $\mathrm{BOD}_{5,0}$ before Fenton treatment. The quantitative relationships between $\mathrm{BOD}_{5} / \mathrm{COD}$ or $\mathrm{BOD}_{5} / \mathrm{BOD}_{5,0}$ with $\mathrm{L}_{\mathrm{COD}}$ should be valid for biodegradability enhancement of mature leachate by Fenton process due to the dimensionless nature of the correlation equations to be established in this study. As a result, it may be used to estimate the amount of oxidant, $\mathrm{H}_{2} \mathrm{O}_{2}$, required to achieve a specific biodegradability improvement in terms of either $\mathrm{BOD}_{5} / \mathrm{COD}$ or $\mathrm{BOD}_{5} / \mathrm{BOD}_{5,0}$.

\section{Materials and Methods}

\subsection{Sampling}

Leachate samples were collected from a lined municipal solid waste landfill located in north Palm Beach County, Florida, with a waste age greater than 20 years. The work presented here refers to the analysis of two distinct leachate samples, labeled as leachates A and B. Leachate A was a mixed leachate collected from all the cells of the landfill. It includes drainage from cells containing municipal solid waste (MSW) and others containing ash from a waste to energy plant. Leachate B was collected from a cell only containing MSW. Samples were placed in a 20-L Nalgene container and stored in a refrigerator at $4{ }^{\circ} \mathrm{C}$ in the dark until used in the experiments.

\subsection{Reagents}

Ultrapure water, with an electrical resistivity higher than $16 \mathrm{Mohms} . \mathrm{cm}^{-1}$ and total organic carbon (TOC) lower than $75 \mu \mathrm{g} . \mathrm{L}^{-1}$, was used in the experiments. Technical grade 
$\mathrm{FeSO}_{4} \cdot 7 \mathrm{H}_{2} \mathrm{O}, \mathrm{NaOH}$ and $\mathrm{H}_{2} \mathrm{SO}_{4}$ were purchased from Fisher Scientific, while $\mathrm{H}_{2} \mathrm{O}_{2}(35 \% \mathrm{w} / \mathrm{w})$ was purchased from Acros Organics.

\subsection{Fenton Experiments}

Batch experiments were conducted using $1 \mathrm{~L}$ of raw leachate, and/or diluted leachate with ultrapure water, in a $2 \mathrm{~L}$ jar test apparatus (Phipps and Bird, Richmond, VA) set at a rotation speed of $100 \mathrm{rpm}$. Before starting the experiments, the leachate samples were brought to room temperature at about $23{ }^{\circ} \mathrm{C}$. Then, the leachate samples were shaken for re-suspension of settled solids and diluted to produce solutions with volumetric ratios ranging from 10 to $83 \%$ $(v / v)$. The $\mathrm{pH}$ range $(2.0-6.0)$ and $\mathrm{H}_{2} \mathrm{O}_{2} / \mathrm{Fe}^{2+}$ ratio $(1.8 \mathrm{w} / \mathrm{w})$ used in the experiments were chosen according to the statistical analysis of optimal Fenton leachate treatment conditions (Singh and Tang 2013). The previously published literature had determined the $\mathrm{H}_{2} \mathrm{O}_{2}$ dose by conducting multiple experiments at a variable number of doses using trial or using different ratios of $\mathrm{H}_{2} \mathrm{O}_{2}$ and COD (Lopez et al. 2004; Goi et al. 2010). In this study, we hypothesized that the selection of Fenton reagent dose should be decided depending upon the amount of available $\mathrm{O}_{2}$ in the form of ${ }^{\bullet} \mathrm{OH}$ that is present for oxidation of organic matter, given by the initial COD value. Therefore, the oxidant $\left(\mathrm{H}_{2} \mathrm{O}_{2}\right)$ dose was based on the ratio of initial COD of leachate landfill and $\mathrm{O}_{2}$ supplied by $\mathrm{H}_{2} \mathrm{O}_{2}$, which is also termed as $\mathrm{L}_{\mathrm{COD}}$ (Eq. 4):

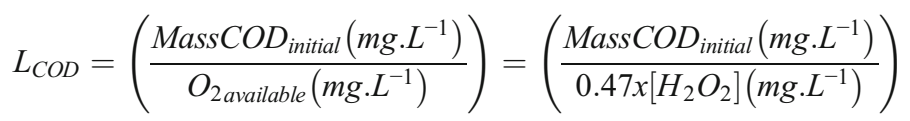

where 'available $\mathrm{O}_{2}$ ' is the theoretical amount of reactive $\mathrm{O}_{2}$ equivalent to the added $\mathrm{H}_{2} \mathrm{O}_{2}$. Theoretically, $1 \mathrm{~mol}$ of $\mathrm{H}_{2} \mathrm{O}_{2}\left(34 \mathrm{~g} \mathrm{H}_{2} \mathrm{O}_{2}\right)$ has $0.50 \mathrm{~mol}$ of available $\mathrm{O}_{2}\left(16 \mathrm{~g} \mathrm{O}_{2}\right)$ for oxidation, according to Eq. (5):

$$
2 \mathrm{H}_{2} \mathrm{O}_{2} \rightarrow 2 \mathrm{H}_{2} \mathrm{O}+\mathrm{O}_{2}
$$

In the first part of this study, experiments were carried out to evaluate the effect of initial $\mathrm{pH}$ of 2.0, 3.5 and 6.0 on TOC removal and biodegradability enhancement, in terms of $\mathrm{BOD}_{5} / \mathrm{COD}$ or $\mathrm{BOD}_{5} / \mathrm{BOD}_{5,0}$ ratios at $\mathrm{L}_{\mathrm{COD}} 0.61$ and $\mathrm{H}_{2} \mathrm{O}_{2} / \mathrm{Fe}^{2+} 1.8(w / w)$. In these essays (experiments $1-$ 3; Table 1), the raw leachate A was diluted by $50 \%(v / v)$, generating different organic load solutions $\left(\mathrm{TOC}=85 \pm 11 \mathrm{mg} . \mathrm{L}^{-1} ; \mathrm{COD}=515 \pm 68 \mathrm{mg} . \mathrm{L}^{-1} ; \mathrm{BOD}_{5}=30 \pm 13 \mathrm{mg} . \mathrm{L}^{-1}\right.$ ). Each experiment was started by stirring the leachate at $100 \mathrm{rpm}$ while $\mathrm{pH}$ was adjusted to a desired value using $10 \mathrm{~mol}$. $\mathrm{L}^{-1} \mathrm{H}_{2} \mathrm{SO}_{4}$ and/or $1 \mathrm{~mol}$. $\mathrm{L}^{-1} \mathrm{NaOH}$. The desired amount of $\mathrm{FeSO}_{4} \cdot 7 \mathrm{H}_{2} \mathrm{O}$ crystals were weighed and dissolved separately in a beaker using leachate from the same jar-test beaker. The dissolved $\mathrm{FeSO}_{4} \cdot 7 \mathrm{H}_{2} \mathrm{O}$ was then added to the stirred leachate. After $1 \mathrm{~min}$, the desired amount of $\mathrm{H}_{2} \mathrm{O}_{2}$ was added in a single step. To monitor the process, $20 \mathrm{~mL}$ sample aliquots were taken from the batch reactor after $0.5,1$ and $5 \mathrm{~min}$, sequentially, followed by coagulation/flocculation/decantation. The $\mathrm{pH}$ was raised to 10 by using $10 \mathrm{~mol}$. $\mathrm{L}^{-1} \mathrm{NaOH}$. After this, the supernatant was collected and kept in the dark at $4{ }^{\circ} \mathrm{C}$ until analyzed for TOC and $\mathrm{BOD}_{5}$. In addition, $\mathrm{pH}$ values greater than 10 also contributed to quench the oxidation reaction by terminating the production of ${ }^{\circ} \mathrm{OH}$ radicals, since the excess of $\mathrm{H}_{2} \mathrm{O}_{2}$ is released as $\mathrm{O}_{2}$ (Papadopoulos et al. 2007). This step is very important to prevent any further reaction, as well as eliminate the $\mathrm{H}_{2} \mathrm{O}_{2}$ interference on COD or $\mathrm{BOD}_{5}$ analysis (Wu and Englehardt 2012).

In the second set of essays (experiments 2 and 4; Table 1), an initial $\mathrm{pH}$ of 3.5 and $\mathrm{H}_{2} \mathrm{O}_{2}$ / $\mathrm{Fe}^{2+} 1.8(w / w)$ were used. Raw leachate A was diluted between 16 and $84 \%(v / v)$ generating different organic loadings $\left([\mathrm{TOC}]=109 \pm 39 \mathrm{mg} \mathrm{L}^{-1}\right.$; $[\mathrm{COD}]=665 \pm 246 \mathrm{mg} \mathrm{L}^{-1} ;\left[\mathrm{BOD}_{5}\right]=52 \pm$ 
Table 1 Experimental conditions used in Fenton leachate treatment, fixing the $\mathrm{H}_{2} \mathrm{O}_{2} / \mathrm{Fe}^{2+}$ ratio at $1.8(w / w)$

\begin{tabular}{|c|c|c|c|c|c|c|c|c|}
\hline \multirow[t]{2}{*}{ Experimental } & \multicolumn{8}{|c|}{ Initial experimental conditions } \\
\hline & $\begin{array}{l}\text { TOC } \\
\left(\mathrm{mg} . \mathrm{L}^{-1}\right)\end{array}$ & $\begin{array}{l}\text { COD } \\
\left(\mathrm{mg} . \mathrm{L}^{-1}\right)\end{array}$ & $\begin{array}{l}\mathrm{BOD}_{5} \\
\left(\mathrm{mg} . \mathrm{L}^{-1}\right)\end{array}$ & $\mathrm{pH}$ & $\mathrm{L}_{\mathrm{COD}}$ & $\begin{array}{l}\mathrm{H}_{2} \mathrm{O}_{2} \\
\left(\mathrm{mg} . \mathrm{L}^{-1}\right)\end{array}$ & $\begin{array}{l}\mathrm{Fe}^{2+} \\
\left(\mathrm{mg} . \mathrm{L}^{-1}\right)\end{array}$ & $\begin{array}{l}\text { Sampling time } \\
\text { (min) }\end{array}$ \\
\hline 1 & 91 & 555 & 18 & 2.0 & 0.61 & 1,944 & 1,080 & $0,0.5,1$ and 5 \\
\hline 2 & 69 & 419 & 47 & 3.5 & 0.61 & 1,458 & 810 & $0,0.5,1$ and 5 \\
\hline 3 & 94 & 571 & 24 & 6.0 & 0.62 & 1,944 & 1,080 & $0,0.5,1$ and 5 \\
\hline 4 & 148 & 912 & 57 & 3.5 & 1.00 & 1,944 & 1,080 & $0,0.5,1$ and 5 \\
\hline 5 & 249 & 1,543 & 30 & 3.5 & 1.12 & 2,916 & 1,620 & 5 \\
\hline 6 & 20 & 111 & 27 & 3.5 & 0.34 & 691 & 384 & 5 \\
\hline 7 & 30 & 171 & 36 & 3.5 & 0.53 & 691 & 384 & 5 \\
\hline 8 & 73 & 442 & 50 & 3.5 & 1.02 & 920 & 511 & 5 \\
\hline 9 & 124 & 763 & 72 & 3.5 & 1.18 & 1,381 & 767 & 5 \\
\hline 10 & 24 & 134 & 36 & 3.5 & 1.14 & 250 & 139 & 5 \\
\hline 11 & 25 & 140 & 30 & 3.5 & 1.19 & 250 & 139 & 5 \\
\hline 12 & 42 & 247 & 55 & 3.5 & 0.22 & 2,324 & 1,291 & 5 \\
\hline 13 & 41 & 239 & 42 & 3.5 & 0.66 & 774 & 430 & 5 \\
\hline 14 & 49 & 289 & 39 & 3.5 & 1.06 & 581 & 323 & 5 \\
\hline 15 & 187 & 1,155 & 124 & 3.5 & 1.06 & 2,324 & 1,291 & 5 \\
\hline 16 & 76 & 460 & 95 & 3.5 & 0.21 & 4,648 & 2,582 & 5 \\
\hline 17 & 96 & 584 & 86 & 3.5 & 0.80 & 1,548 & 860 & 5 \\
\hline 18 & 89 & 544 & 105 & 3.5 & 1.00 & 1,161 & 645 & 5 \\
\hline
\end{tabular}

TOC total organic carbon, $\mathrm{COD}$ chemical oxygen demand, $\mathrm{BOD}_{5}$ biochemical oxygen demand after 5 days, $\mathrm{L}_{\mathrm{COD}} \mathrm{COD}$ loading factor

$\left.5 \mathrm{mg} \mathrm{L}^{-1}\right)$. The influence of the $\mathrm{L}_{\mathrm{COD}}(0.61$ and 1.00) on the TOC removal and biodegrad ability enhancement was evaluated. Samples were withdrawn after $0.5,1$ and 5 min. Finally, a set of 16 experiments were carried out by using raw leachate A and B. Leachates A and B were diluted between 16 and $90 \%(v / v)$ to produce different $\mathrm{L}_{\mathrm{COD}}$ values ranging from 0.22 to 1.19 (experiments 2, 4-18; Table 1), respectively. Different organic load solutions were prepared, being for leachate A: $[\mathrm{TOC}]=85 \pm 72 \mathrm{mg} \mathrm{L}^{-1}$; $[\mathrm{COD}]=515 \pm 454 \mathrm{mg} \mathrm{L}^{-1}$; $\left[\mathrm{BOD}_{5}\right]=$ $43 \pm 14 \mathrm{mg} \mathrm{L}^{-1}$; and, for leachate $\mathrm{B}$ : $[\mathrm{TOC}]=83 \pm 47 \mathrm{mg} \mathrm{L}^{-1}$; $[\mathrm{COD}]=512 \pm 278 \mathrm{mg} \mathrm{L}^{-1}$; $\left[\mathrm{BOD}_{5}\right]=78 \pm 30 \mathrm{mg} \mathrm{L}^{-1}$. The $\mathrm{H}_{2} \mathrm{O}_{2} / \mathrm{Fe}^{2+}$ mass ratio and $\mathrm{pH}$ were kept constant at 1.8 and 3.5 , respectively. The results were used to estimate the relation between biodegradability (in terms of $\mathrm{BOD}_{5} / \mathrm{COD}$ or $\left.\mathrm{BOD}_{5} / \mathrm{BOD}_{5,0}\right)$ and $\mathrm{L}_{\mathrm{COD}}$ after 5 min reaction of Fenton process. The same procedure made in the first set of experiments after sampling was followed in the second and last sets of experiments.

\subsection{Analysis}

TOC was measured using a Shimadzu TOC-VCPH TOC analyzer equipped with an ASI-V autosampler. COD measurements followed the Standard Methods 5220 D (colorimetric method; Clesceri et al. 2005). Although $10 \mathrm{~mol} . \mathrm{L}^{-1} \mathrm{NaOH}$ were added to the samples (eliminating the residual $\mathrm{H}_{2} \mathrm{O}_{2}$ and its interference on COD analysis), for simplicity, a relationship between TOC and COD of raw leachate was developed and established by analyzing multiple raw leachate samples at various dilutions. So, samples generated during 
the Fenton oxidation of leachate were analyzed for TOC and the corresponding COD values were obtained using the relationship between TOC and $C O D(C O D=6.18$ TOC $=0.32$; $\left.\mathrm{R}^{2}=0.98\right)$.

BOD measurements followed the Standard Method 5210B (dilution method and thermostated at $20^{\circ} \mathrm{C}$ for 5 days; Clesceri et al. 2005). BOD dilution water was freshly prepared for each experiment batch by dissolving Hach ${ }^{\circledR}$ BOD nutrient buffer pillows in ultrapure water in the proportion prescribed by the manufacturer. Dilution water was prepared in a sterile Nalgene carboy and stored in the incubator for up to $24 \mathrm{~h}$ prior to setting up a $\mathrm{BOD}_{5}$ experiment set. On the start day of an experiment, a solution of the inoculum was prepared by following the PolySeed ${ }^{\circledR}$ normal dilution, rehydration and activation procedure. This consisted of one capsule to $500 \mathrm{~mL}$ of dilution water placed in a beaker and stirred on a magnetic stirring plate while simultaneously aerating the mix for one hour prior to use. Likewise, the dilution water was also aerated beginning one hour prior to setting up the $\mathrm{BOD}_{5}$ experiment. Prior to $\mathrm{BOD}_{5}$ testing, the $\mathrm{pH}$ of each sample was adjusted to $7.0 \pm 0.2$ by using small volumes of 9 mol. $\mathrm{L}^{-1} \mathrm{H}_{2} \mathrm{SO}_{4}$ and $5 \mathrm{~mol}$. $\mathrm{L}^{-1} \mathrm{NaOH}$ solutions, as needed. Volumes added to achieve the correct $\mathrm{pH}$ were less than $250 \mu \mathrm{L}$ per sample. Aliquots of the samples leachate were measured with a pipette and placed directly into the BOD bottles. Each bottle was then successively filled with a portion of the BOD dilution water, $4 \mathrm{~mL}$ of the PolySeed ${ }^{\circledR}$ solution, and BOD dilution water filling the bottle half-way up to the etched bottle's neck. Before carrying out the analyses of $\mathrm{BOD}_{5}$ to the samples obtained during application of the Fenton process, a previous study was done to evaluate the effect of the leachate dilution (ranging from 1 to $12 \% v / v$ ) on $\mathrm{BOD}_{5}$ analysis. Optimal $\mathrm{v} / \mathrm{v}$ was determined and used in further analyses. The initial DO measurement was taken immediately after each bottle was filled, after which the stopper was tightly secured on the bottle, and this was placed in the incubator. Final DO measurements were taken after 5 days $\pm 1 \mathrm{~h}$.

The $\mathrm{BOD}_{5}$ were computed using the following equation:

$$
\mathrm{BOD}_{5}=\frac{\left(\mathrm{D}_{1}-\mathrm{D}_{2}\right)-\left(\mathrm{B}_{1}-\mathrm{B}_{2}\right) \cdot f}{\mathrm{P}}
$$

where $\mathrm{BOD}_{5}$ is the 5 day biochemical oxygen demand $\left(\mathrm{mg} . \mathrm{L}^{-1}\right) ; \mathrm{D}_{1}$ is the $\mathrm{DO}$ of the diluted sample immediately after preparation $\left(\mathrm{mg} . \mathrm{L}^{-1}\right) ; \mathrm{D}_{2}$ is the DO of the diluted sample after incubation for 5 days $\pm 1 \mathrm{~h}$ at $20^{\circ} \mathrm{C}\left(\mathrm{mg} . \mathrm{L}^{-1}\right) ; \mathrm{B}_{1}$ is the DO of seeded dilution water blank before incubation $\left(\mathrm{mg} . \mathrm{L}^{-1}\right) ; \mathrm{B}_{2}$ is the DO of seeded dilution water blank after incubation $\left(\mathrm{mg} . \mathrm{L}^{-1}\right) ; f$ is the ratio of seed in sample to seed in blank $=\frac{\% \text { seed in } \mathrm{D}_{1}}{\% \text { seed in } \mathrm{B}_{1}}$; and $\mathrm{P}$ is the decimal fraction of sample used $=\frac{\mathrm{mL} \text { of sample }}{300 \mathrm{~mL}}$

Control samples were prepared and incubated with each experiment's batch to assure compliance with standard test criteria (Clesceri et al. 2005). These control samples consisted of two dilution water blanks, three seed control, and two glucose/glutamic acid standards. The dissolved oxygen probe was calibrated for each experiment using the two point calibration procedure: with a zero oxygen solution and water-saturated air, as described in the instrument's manual.

\section{Results and Discussion}

\subsection{Leachate Characterization}

Major relevant water quality parameters of the leachate samples A and B are shown in Table 2, respectively. In general, the low average values of $\mathrm{BOD}_{5}$ of leachates $\mathrm{A}$ 
Table 2 Important relevant parameters of two investigated landfill leachate samples

\begin{tabular}{|c|c|c|}
\hline Parameter & Leachate A & Leachate B \\
\hline pH & 7.8 & 7.5 \\
\hline Dissolved oxygen $\left(\mathrm{mg} . \mathrm{L}^{-1}\right)$ & 2.6 & 2.6 \\
\hline Alkalinity, as $\mathrm{CaCO}_{3}\left(\mathrm{mg} . \mathrm{L}^{-1}\right)$ & $2,385 \pm 35$ & $2,345 \pm 57$ \\
\hline Total dissolved solids (mg. $\mathrm{L}^{-1}$ ) & $7,057 \pm 243$ & $19,066 \pm 757$ \\
\hline Total organic carbon, COD $\left(\mathrm{mg} . \mathrm{L}^{-1}\right)$ & $318 \pm 52$ & $777 \pm 73$ \\
\hline Chemical oxygen demand, COD $\left(\mathrm{mg} . \mathrm{L}^{-1}\right)$ & $1,092 \pm 151$ & $2,184 \pm 50$ \\
\hline Biochemical oxygen demand, $\mathrm{BOD}_{5}\left(\mathrm{mg} \cdot \mathrm{L}^{-1}\right)$ & $38 \pm 10$ & $151 \pm 50$ \\
\hline $\mathrm{BOD}_{5} / \mathrm{COD}$ & 0.035 & 0.069 \\
\hline
\end{tabular}

and $\mathrm{B}\left(38\right.$ and $\left.151 \mathrm{mg} . \mathrm{L}^{-1}\right)$, and the low biodegradability, in terms of $\mathrm{BOD}_{5} / \mathrm{COD}$ ratios (0.035 and 0.069), indicate typical characteristics of a stabilized leachate (Tchobanoglous et al. 1993). Comparing the two leachate samples, the significantly lower initial values of $\mathrm{BOD}_{5}$ and $\mathrm{BOD}_{5} / \mathrm{COD}$ ratio measured in leachate $\mathrm{A}$ compared to $\mathrm{B}$ are an indication that leachate $\mathrm{A}$ contains a larger proportion of more recalcitrant organic pollutants than leachate B.

\subsection{Influence of $\mathrm{pH}$ on TOC Removal and Biodegradability Enhancement}

The effect of $\mathrm{pH}$ on the Fenton process (during the first $5 \mathrm{~min})$ of leachate A $(50 \% v / v)$ was studied at a $\mathrm{L}_{\mathrm{COD}}$ of 0.61 and a mass ratio $\mathrm{H}_{2} \mathrm{O}_{2} / \mathrm{Fe}^{2+}$ of 1.8 to evaluate the profile of the leachate TOC removal and the biodegradability enhancement during the reaction time at different $\mathrm{pH}$ values $(2.0,3.5$ and 6.0).

Figure 1a suggests that the maximum TOC removal efficiency by the Fenton process occurred at $\mathrm{pH}$ of 3.5, with a removal efficiency of $61 \%$, followed by $40 \%$ and $29 \%$ at $\mathrm{pH}$ values of 6.0 and 2.0, respectively. At each $\mathrm{pH}$, the TOC removal increased sharply during the initial $1 \mathrm{~min}$ of the reaction, and then leveled off until $5 \mathrm{~min}$ of reaction. The optimal $\mathrm{pH}$ of 3.5 observed in this study is consistent with prior studies, which reported that the optimum $\mathrm{pH}$ for
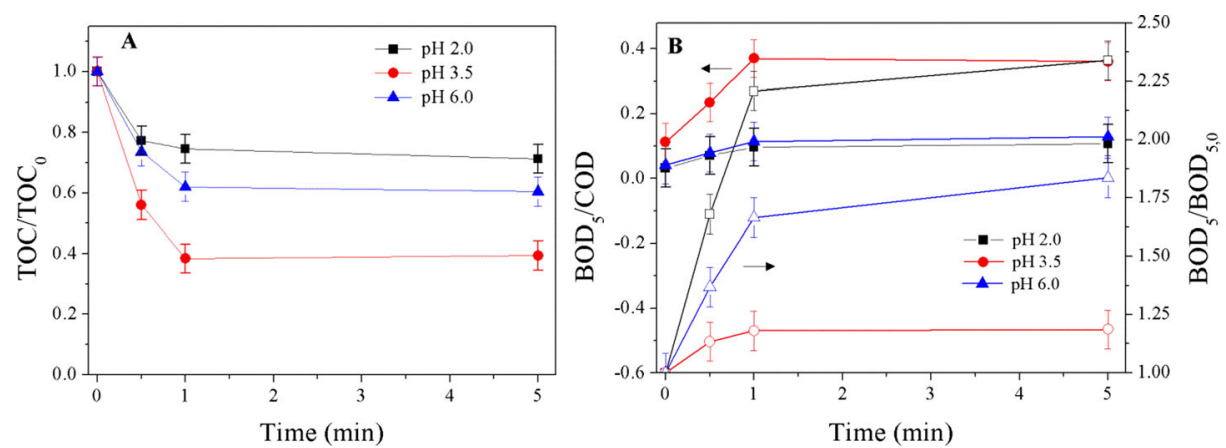

Fig. 1 Influence of the initial $\mathrm{pH}$ on the $\mathbf{a}$ TOC removal and $\mathbf{b}$ biodegradability enhancement of leachate $\mathrm{A}$, in terms of $\mathrm{BOD}_{5} / \mathrm{COD}$ (solid symbols) and $\mathrm{BOD}_{5} / \mathrm{BOD}_{5,0}$ (open symbols) ratios. Initial conditions: $[\mathrm{TOC}]=85 \pm$ $11 \mathrm{mg} \mathrm{L}{ }^{-1} ;[\mathrm{COD}]=515 \pm 68 \mathrm{mg} \mathrm{L}^{-1} ;\left[\mathrm{BOD}_{5}\right]=30 \pm 13 \mathrm{mg} \mathrm{L}^{-1} ; \mathrm{L}_{\mathrm{COD}}=0.61 ; \mathrm{H}_{2} \mathrm{O}_{2} / \mathrm{Fe}^{2+}(\mathrm{w} / \mathrm{w})=1.8 ;\left[\mathrm{H}_{2} \mathrm{O}_{2}\right]=$ $1,782 \pm 229 \mathrm{mg} \mathrm{L}^{-1} ;\left[\mathrm{Fe}^{2+}\right]=990 \pm 127 \mathrm{mg} \mathrm{L}^{-1}$ 
Fenton reactions varied from 2.6 to 3.5 (Pignatello 1992; Nogueira and Guimarães 2000). At extremely low $\mathrm{pH}(<2.0)$, the degradation efficiency of TOC decreased due to lower reaction rate of $\left[\mathrm{Fe}\left(\mathrm{H}_{2} \mathrm{O}\right)\right]^{2+}$ and scavenging of ${ }^{\circ} \mathrm{OH}$ by $\mathrm{H}^{+}$(Nogueira et al. 2007; Machulek et al. 2012). On the other hand, at high $\mathrm{pH}$ values $(>5.0)$, the reduction of degradation efficiency was primarily due to increased rate of auto-decomposition of $\mathrm{H}_{2} \mathrm{O}_{2}$, deactivation of iron ion into iron oxyhydroxides, increased scavenging of ${ }^{\circ} \mathrm{OH}$ by carbonate and bicarbonate, and decreased oxidation potential of ${ }^{\circ} \mathrm{OH}$. During the first minute, $\mathrm{Fe}^{2+}$ rapidly catalyzes the formation of ${ }^{\circ} \mathrm{OH}$ from $\mathrm{H}_{2} \mathrm{O}_{2}$. The hydroxyl radical produced rapidly oxidizes the dissolved organic matter present in the leachate. After $1 \mathrm{~min}$, the concentration of ${ }^{\circ} \mathrm{OH}$ is very low due to limited availability of $\mathrm{Fe}^{2+}$. The regeneration rate of $\mathrm{Fe}^{2+}\left(10^{-3}-10^{-2} \mathrm{M}^{-1} \cdot \mathrm{s}^{-1}\right)$ is approximately four orders slower than $\mathrm{Fe}^{2+}$ consumption $\left(76 \mathrm{M}^{-1} \cdot \mathrm{s}^{-1}\right.$ ) (Eq. 3) (Umar et al. 2010). Therefore, a slower process resulted in the second phase after $5 \mathrm{~min}$ of reaction.

A similar behavior was observed for biodegradability enhancement in terms of $\mathrm{BOD}_{5} / \mathrm{COD}$ ratio (Fig. 1b). The maximum biodegradability improvement expressed by.

$\mathrm{BOD}_{5} / \mathrm{COD}$ ratio increased from 0.11 to 0.37 after $1 \mathrm{~min}$ at $\mathrm{pH} 3.5$, while during this same period the average biodegradability increased only from 0.037 to 0.095 at $\mathrm{pH} 2.0$ and 6.0, respectively. The rapid increase of leachate's biodegradability in terms of $\mathrm{BOD}_{5} / \mathrm{COD}$ ratio at the initial stage of reaction is consistent with the expected oxidation of larger organic matter, such as humic and fulvic compounds, by high initial concentrations ${ }^{\circ} \mathrm{OH}$. As a result, a larger amount of smaller organic compounds would be produced and result in high $\mathrm{BOD}_{5}$ (de Morais and Zamora 2005; Batarseh et al. 2007). The magnitude of the biodegradability improvements of this stabilized leachate are also in agreement with data published in the literature for mature landfill leachates. For example, de Morais and Zamora (2005) observed that the Fenton treatment increased leachate biodegradability, e.g., the ratio $\mathrm{BOD}_{5} / \mathrm{COD}$ from 0.13 to 0.42 . This $223 \%$ increase of $\mathrm{BOD}_{5} / \mathrm{COD}$ ratio is comparable with our observed $236 \%$ increase of the $\mathrm{BOD}_{5} / \mathrm{COD}$ ratio. In this study, no further improvement of the biodegradability of the leachate (Fig. 1b) after 1 min was observed at all $\mathrm{pH}$ values studied, similar to what we had noted for the TOC removal (Fig. 1a).

When biodegradability was measured in terms of $\mathrm{BOD}_{5} / \mathrm{BOD}_{5,0}$ ratio, an improvement of this ratio was observed in the order: $\mathrm{pH} 2.0>6.0>3.5$ (Fig. 1b). That is, biodegradability improvement was the lowest when the reaction was conducted at an initial $\mathrm{pH}$ of 3.5 followed by $\mathrm{pH}$ values of 6.0 and 2.0 (Fig. 1b). At $\mathrm{pH}$ of $2.0, \mathrm{BOD}_{5}$ increased to more than 2.3 times of the initial $\mathrm{BOD}_{5}$ after 5 min of Fenton oxidation. At the initially adjusted $\mathrm{pH}$ of 3.5 and 6.0 , the increase in $\mathrm{BOD}_{5}$ after the same reaction time was only 1.2 and 1.8 times, respectively. The difference in the biodegradability enhancement, in terms of $\mathrm{BOD}_{5} / \mathrm{COD}$ and $\mathrm{BOD}_{5} / \mathrm{BOD}_{5,0}$, in relation to $\mathrm{pH}$ can be explained based on the results of decreased COD and increased $\mathrm{BOD}_{5}$ (Table 3). Considering the $\mathrm{BOD}_{5} / \mathrm{COD}$ ratio at a $\mathrm{pH}$ value of 3.5 , although a small increase on the measured $\mathrm{BOD}_{5}$ was observed, a higher COD removal was noted (Table 3-Exp. 2), yielding a high $\mathrm{BOD}_{5} / \mathrm{COD}$ ratio. Although a low TOC and COD removal (Fig. 1a and Table 3-Exp. 1 and 3) were obtained at $\mathrm{pH}$ 2.0, more biodegradable oxidized by-products were yielded because the $\mathrm{BOD}_{5} / \mathrm{BOD}_{5,0}$ ratio increased significantly (Fig. 1b). These results suggest that the Fenton process can be used at a $\mathrm{pH}$ near the neutral value as a pre-treatment method, which would result in the production of biodegradable compounds, thus making the leachate amenable to biological treatment. It is important to emphasize that the value of $\mathrm{BOD}_{5} /$ COD ratio obtained at $\mathrm{pH} 6$ still indicates a leachate containing compounds relatively hard to biodegrade. Although the Fenton process can be applied as a pre-treatment in a wide $\mathrm{pH}$ range (between 2.0 and 6.0), all subsequent experiments were conducted at an initial $\mathrm{pH}$ of 3.5 , due to better TOC removal and biodegradability enhancement in terms of $\mathrm{BOD}_{5} / \mathrm{COD}$. The 
Table 3 Results of $\mathrm{COD}$ and $\mathrm{BOD}_{5}$ obtained before and during the Fenton treatment to different initial experimental conditions

\begin{tabular}{|c|c|c|c|c|c|c|c|c|}
\hline \multirow[t]{4}{*}{ Experimental } & \multicolumn{8}{|c|}{ Sampling time (min) } \\
\hline & \multicolumn{2}{|l|}{0} & \multicolumn{2}{|l|}{0.5} & \multicolumn{2}{|l|}{1} & \multicolumn{2}{|l|}{5} \\
\hline & \multicolumn{8}{|c|}{ Concentration $\left(\mathrm{mg} \cdot \mathrm{L}^{-1}\right)$} \\
\hline & $\mathrm{COD}$ & $\mathrm{BOD}_{5}$ & $\mathrm{COD}$ & $\mathrm{BOD}_{5}$ & COD & $\mathrm{BOD}_{5}$ & $\mathrm{COD}$ & $\mathrm{BOD}_{5}$ \\
\hline 1 & 555 & 18 & 425 & 30 & 410 & 40 & 391 & 42 \\
\hline 2 & 419 & 47 & 227 & 53 & 150 & 56 & 155 & 56 \\
\hline 3 & 571 & 24 & 416 & 33 & 348 & 40 & 338 & 44 \\
\hline 4 & 912 & 57 & 568 & 64 & 490 & 72 & 475 & 61 \\
\hline 5 & 1,543 & 30 & 920 & 63 & 937 & 64 & 937 & 89 \\
\hline 6 & 111 & 27 & - & - & - & - & 68 & 30 \\
\hline 7 & 171 & 36 & - & - & - & - & 117 & 43 \\
\hline 8 & 442 & 50 & - & - & - & - & 334 & 52 \\
\hline 9 & 763 & 72 & - & - & - & - & 542 & 89 \\
\hline 10 & 134 & 36 & - & - & - & - & 134 & 25 \\
\hline 11 & 140 & 30 & - & - & - & - & 141 & 29 \\
\hline 12 & 247 & 55 & - & - & - & - & 151 & 83 \\
\hline 13 & 239 & 42 & - & - & - & - & 174 & 46 \\
\hline 14 & 289 & 39 & - & - & - & - & 232 & 45 \\
\hline 15 & 1,155 & 124 & - & - & - & - & 874 & 134 \\
\hline 16 & 460 & 95 & - & - & - & - & 241 & 120 \\
\hline 17 & 584 & 86 & - & - & - & - & 436 & 80 \\
\hline 18 & 544 & 105 & - & - & - & - & 424 & 107 \\
\hline
\end{tabular}

reaction time of 5 min was selected because there was an improvement on the $\mathrm{BOD}_{5}$ compared to the samples obtained after $1 \mathrm{~min}$ (Fig. $1 \mathrm{~b}$ and Table 3).

\subsection{Influence of $\mathrm{L}_{\mathrm{COD}}$ on TOC Removal and Biodegradability Enhancement}

The Fenton reaction can also be significantly influenced by the dose of the chemical reagents, such as $\mathrm{Fe}^{2+}, \mathrm{H}_{2} \mathrm{O}_{2}$, as well as the $\mathrm{H}_{2} \mathrm{O}_{2} / \mathrm{Fe}^{2+}$ ratio (Tang 2004). If $\mathrm{Fe}^{2+}$ is overdosed, the ${ }^{\circ} \mathrm{OH}$ radical would be scavenged by the $\mathrm{Fe}^{2+}$ in excess (De Laat and Gallard 1999), while the excess $\mathrm{H}_{2} \mathrm{O}_{2}$ will also react with the hydroxyl radical without promoting the degradation of organic matter (Nogueira et al. 2007; Melo et al. 2009; Jiang et al. 2010; Trovó et al. 2013). In either cases, the degradation efficiency of leachate will decrease. Therefore, the optimal mass $\mathrm{H}_{2} \mathrm{O}_{2} /$ $\mathrm{Fe}^{2+}$ ratio has to be maintained at optimal condition. According to the median of the optimal ratios from the peer reviewed publications statistically analyzed by Singh and Tang (2013), this mass ratio was selected at $1.8(w / w)$ in all the experiments in this study. It should be pointed out that this value can greatly fluctuate according to the type of pollutants and the water quality matrix in the leachate.

When the $\mathrm{H}_{2} \mathrm{O}_{2} / \mathrm{Fe}^{2+}$ ratio is maintained constant at $1.8(w / w)$, the steady-state concentration of hydroxyl radical depends upon the dose of $\mathrm{H}_{2} \mathrm{O}_{2}$. To assess the relationship between TOC removal and biodegradability enhancement during the Fenton process, experiments using 
two $\mathrm{L}_{\mathrm{COD}}$ values of 1.00 and 0.61 were performed using leachate A diluted between 16 and $84 \%(v / v)$, respectively. The initial solutions of the leachate used were prepared at different COD loads: $\left([\mathrm{TOC}]=109 \pm 39 \mathrm{mg} \mathrm{L}^{-1}\right.$; $[\mathrm{COD}]=665 \pm 246 \mathrm{mg} \mathrm{L}^{-1}$; $\left.\left[\mathrm{BOD}_{5}\right]=52 \pm 5 \mathrm{mg} \mathrm{L}^{-1}\right)$. Since the COD removal has a linear dependence on $\mathrm{L}_{\mathrm{COD}}$ (Singh et al. 2013), the effect of organic load, $\mathrm{L}_{\mathrm{COD}}$, on TOC removal and biodegradability enhancement was experimentally investigated as shown in Fig. 2.

Figure 2a shows that the TOC removal increased as $\mathrm{L}_{\mathrm{COD}}$ decreased from 1.00 to 0.61. At a lower $\mathrm{L}_{\mathrm{COD}}$, a higher amount of $\mathrm{H}_{2} \mathrm{O}_{2}$, and consequently, a higher steadystate concentration of hydroxyl radical was available for oxidizing the $\mathrm{OM}$ in leachate. When the $\mathrm{L}_{\mathrm{COD}}$ increased from 0.61 to 1.00 , the TOC removal decreased from 60 to $40 \%$ (Fig. 2a) after $1 \mathrm{~min}$, and leveled off up to $5 \mathrm{~min}$. The same behavior was observed for biodegradability enhancement in terms of $\mathrm{BOD}_{5} / \mathrm{COD}$ or $\mathrm{BOD}_{5} / \mathrm{BOD}_{5,0}$ ratios (Fig. 2b). When $\mathrm{L}_{\mathrm{COD}}$ increased from 0.61 to 1.00 , the improvement of biodegradability in terms of $\mathrm{BOD}_{5} / \mathrm{COD}$ increased after $1 \mathrm{~min}$ from $0.11-0.062$ to $0.37-0.15$, respectively (Fig. 2b). On the other hand, a better improvement of the biodegradability, in terms of measured $\mathrm{BOD}_{5}$, was obtained at the high $\mathrm{L}_{\mathrm{COD}}$ value for the first minute. After $5 \mathrm{~min}$, the same behavior as that observed for $\mathrm{BOD}_{5} / \mathrm{COD}$ ratio appeared in Fig. 2b. Although a lower TOC removal was obtained at the lower $\mathrm{L}_{\mathrm{COD}}$ value, the use of this COD loading factor of 0.61 rather than the higher $\mathrm{L}_{\mathrm{COD}}$ of 1.00 is extremely advantageous when the Fenton process is used for pre-treatment, due to the lower amount of required chemical reagents.

In parallel, a set of sixteen experiments with $\mathrm{L}_{\mathrm{COD}}$ ranging from 0.22 to 1.19 were conducted to determine the relation between biodegradability enhancement (in terms of either $\mathrm{BOD}_{5} / \mathrm{COD}$ or $\mathrm{BOD}_{5} / \mathrm{BOD}_{5,0}$ ) and $\mathrm{L}_{\mathrm{COD}}$ (Fig. 3) for leachates $\mathrm{A}$ and $\mathrm{B}$. Figure 3 shows that when $\mathrm{L}_{\mathrm{COD}}$ was less than 0.8 , the $\mathrm{BOD}_{5} / \mathrm{COD}$ ratio increased with decreasing $\mathrm{L}_{\mathrm{COD}}$. However, when $\mathrm{L}_{\mathrm{COD}}$ was greater than 0.8 , the $\mathrm{BOD}_{5} / \mathrm{COD}$ ratio remained at a relatively constant level. However, the lower COD removal was observed during the experiment using lower $\mathrm{L}_{\mathrm{COD}}$ (Tables 1 and 3), due to the lower amount of ${ }^{\circ} \mathrm{OH}$ available to oxidize the $\mathrm{OM}$.

There was a slight difference in the initial $\mathrm{BOD}_{5,0}$ of leachates $\mathrm{A}$ and $\mathrm{B}$, as shown in Table 2. For both leachates, the profile of the biodegradability in terms of $\mathrm{BOD}_{5} / \mathrm{COD}$ or $\mathrm{BOD}_{5,0} / \mathrm{BOD}_{5}$ enhancement followed a linear dependence with $\mathrm{L}_{\mathrm{COD}}\left(R^{2}=0.87\right.$ and 0.51 ,
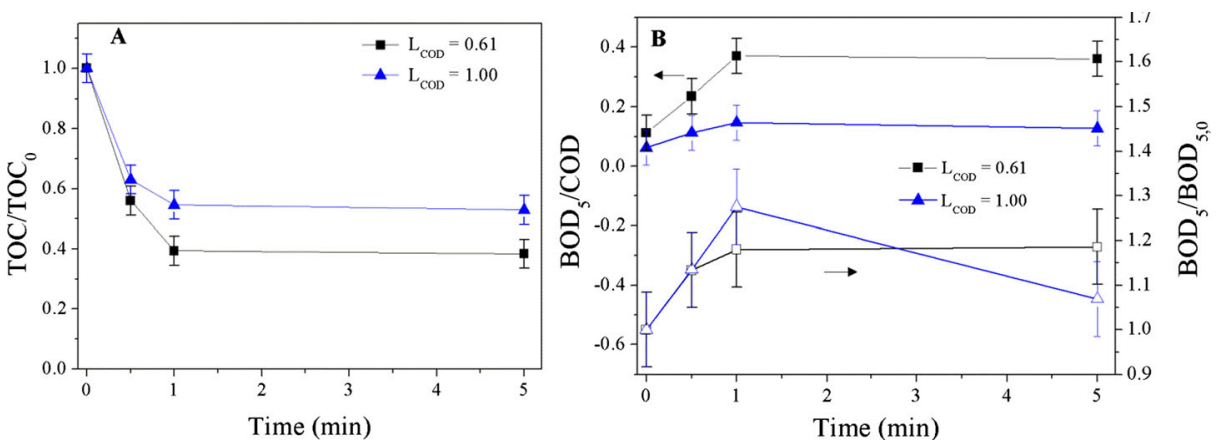

Fig. 2 Influence of $\mathrm{L}_{\mathrm{COD}}$ on a TOC removal and $\mathbf{b}$ biodegradability enhancement, in terms of $\mathrm{BOD}_{5} / \mathrm{COD}$ (solid symbols) and $\mathrm{BOD}_{5} / \mathrm{BOD}_{5,0}$ (open symbols) ratios, of leachate A. Initial conditions: [TOC] $=109 \pm$ $39 \mathrm{mg} \mathrm{L}^{-1}$; $[\mathrm{COD}]=665 \pm 246 \mathrm{mg} \mathrm{L}{ }^{-1} ;\left[\mathrm{BOD}_{5}\right]=52 \pm 5 \mathrm{mg} \mathrm{L}^{-1} ; \mathrm{H}_{2} \mathrm{O}_{2} / \mathrm{Fe}^{2+}(\mathrm{w} / \mathrm{w})=1.8 ;\left[\mathrm{H}_{2} \mathrm{O}_{2}\right]=1,701 \pm$ $243 \mathrm{mg} \mathrm{L}^{-1} ;\left[\mathrm{Fe}^{2+}\right]=945 \pm 135 \mathrm{mg} \mathrm{L}^{-1}$ 

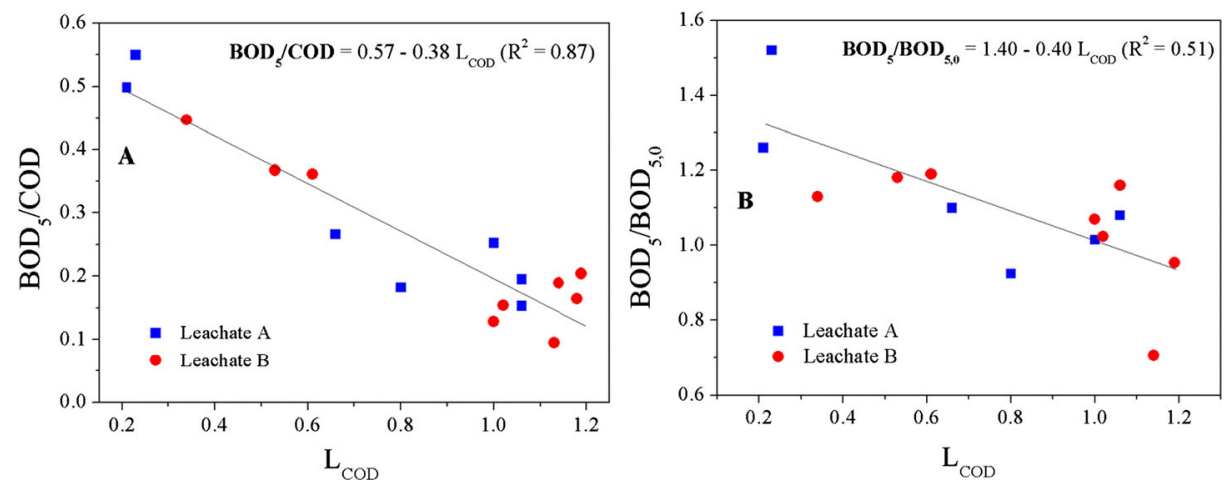

Fig. 3 Relation between the $\mathrm{L}_{\mathrm{COD}}$ and biodegradability enhancement, in terms of a $\mathrm{BOD}_{5} / \mathrm{COD}$ and $\mathbf{b} \mathrm{BOD}_{5} /$ $\mathrm{BOD}_{5,0}$, obtained after $5 \mathrm{~min}$ of the Fenton process for leachates $\mathrm{A}$ and $\mathrm{B}$. Initial conditions: Leachate A: $[\mathrm{TOC}]=85 \pm 72 \mathrm{mg} \mathrm{L}^{-1} ;[\mathrm{COD}]=515 \pm 454 \mathrm{mg} \mathrm{L}^{-1} ;\left[\mathrm{BOD}_{5}\right]=43 \pm 14 \mathrm{mg} \mathrm{L}^{-1} ; \mathrm{H}_{2} \mathrm{O}_{2} / \mathrm{Fe}^{2+}(\mathrm{w} / \mathrm{w})=1.8 ;\left[\mathrm{H}_{2} \mathrm{O}_{2}\right]=$ $1,167 \pm 816 \mathrm{mg} \mathrm{L}^{-1} ;\left[\mathrm{Fe}^{2+}\right]=648 \pm 453 \mathrm{mg} \mathrm{L}^{-1}$; Leachate $B:[\mathrm{TOC}]=83 \pm 47 \mathrm{mg} \mathrm{L}^{-1} ;[\mathrm{COD}]=512 \pm 278 \mathrm{mg} \mathrm{L}^{-1}$; $\left[\mathrm{BOD}_{5}\right]=78 \pm 30 \mathrm{mg} \mathrm{L}^{-1} ; \mathrm{H}_{2} \mathrm{O}_{2} / \mathrm{Fe}^{2+}(\mathrm{w} / \mathrm{w})=1.8 ;\left[\mathrm{H}_{2} \mathrm{O}_{2}\right]=1,908 \pm 1,287 \mathrm{mg} \mathrm{L}^{-1} ;\left[\mathrm{Fe}^{2+}\right]=1,060 \pm 715 \mathrm{mg} \mathrm{L}^{-1}$

respectively), with slopes of 0.38 and 0.40 , respectively (for $\mathrm{L}_{\mathrm{COD}}$ ranging from 0.22 to 1.19 ; Fig. 3). The derived equation from the linear regression can be expressed as follows:

$$
\mathrm{BOD}_{5} / \mathrm{COD}=0.57-0.38 \mathrm{~L}_{\mathrm{COD}}
$$

Equation (7) presents the relation between $\mathrm{BOD}_{5} / \mathrm{COD}$ and $\mathrm{L}_{\mathrm{COD}}$ with a robust correlation coefficient $R^{2}$ of 0.87 . It suggests that when $\mathrm{L}_{\mathrm{COD}}$ approaches zero, the maximum obtainable biodegradability in terms of $\mathrm{BOD}_{5} / \mathrm{COD}$ is 0.57 , which is about 10 times higher than the average $\mathrm{BOD}_{5} / \mathrm{COD}$ of 0.052 for leachates $\mathrm{A}$ and $\mathrm{B}$. Theoretically, the Fenton process should reach its maximal efficiency as $\mathrm{L}_{\mathrm{COD}}$ approaches one. However, as reported by Singh et al. (2013), the maximum efficiency in oxidizing COD occurred at $\mathrm{L}_{\mathrm{COD}}$ of 0.75 when the $\mathrm{H}_{2} \mathrm{O}_{2}$ / $\mathrm{Fe}^{2+}$ mass ratio was 1.8. As a result, the $\mathrm{BOD}_{5} / \mathrm{COD}$ ratio should level off starting from 0.75 . Figure 3a shows that this initial point apparently started at $\mathrm{L}_{\mathrm{COD}}$ of 0.8 .

Similarly, Eq. (8) shows the statistical correlation between $\mathrm{BOD}_{5} / \mathrm{BOD}_{5,0}$ and $\mathrm{L}_{\mathrm{COD}}$. Although the correlation of determination $R^{2}$ of 0.51 was not as robust as that of Eq. (7), the primary downtrend is confirmed with a negative slope of 0.40 .

$$
\mathrm{BOD}_{5} / \mathrm{BOD}_{5,0}=1.40-0.40 \mathrm{~L}_{\mathrm{COD}}
$$

Since $\mathrm{BOD}_{5} / \mathrm{BOD}_{5,0}$ reflects the ratio of the biodegradable organic compounds after the Fenton process to its initial $\mathrm{BOD}_{5,0}$, the maximum obtainable degradability increase would be 1.40 as $\mathrm{L}_{\mathrm{COD}}$ approaches 0.0 (as suggested by Eq. 8). It is important to note that the value 1.40 only reflects the biodegradable organic portion remaining in the leachate after the Fenton process. Therefore, a maximum $\mathrm{BOD}_{5} / \mathrm{BOD}_{5,0}$ of 1.4 is significantly less than ten times $\mathrm{BOD}_{5} / \mathrm{COD}$ increase during the oxidation alone. This is because the main portion of oxidized COD was expected to be in the final products, such as $\mathrm{CO}_{2}$ which does not contribute to $\mathrm{BOD}_{5}$ of the treated leachate by the Fenton process. In addition, the minimum value of $\mathrm{BOD}_{5} / \mathrm{BOD}_{5,0}$ was observed at $\mathrm{L}_{\mathrm{COD}}$ of 0.8 . Since the soluble $\mathrm{BOD}_{5}$ increase after the Fenton process has to result from COD oxidation, it is not surprised that the slopes of both Eqs. (7) and (8) are similar to the slope for the Fenton process in COD reduction of 0.38 , as also reported by Singh et al. (2013). 


\section{Conclusions}

A concomitant improvement of both TOC removal and biodegradability enhancement in terms of $\mathrm{BOD}_{5} / \mathrm{COD}$ ratio was observed when the Fenton reaction was performed on mature landfill leachate at the initial $\mathrm{pH}$ of 3.5. Our experimental results show that the Fenton process still improves mature leachate biodegradability at $\mathrm{pH} 6$, with an observed $\mathrm{BOD}_{5}$ increase of 1.8 times its initial value $\mathrm{BOD}_{5,0}$. The low value of $\mathrm{BOD}_{5} / \mathrm{COD}$ ratio obtained at a $\mathrm{pH}$ value of 6 suggests a leachate containing a significant amount of non-biodegradable compounds. High $\mathrm{L}_{\mathrm{COD}}$ can be employed during pre-treatment of leachate by the Fenton process, since an improvement on biodegradability could be achieved by using relatively lower chemical doses. Leachate biodegradability in terms of $\mathrm{BOD}_{5} / \mathrm{COD}$ or $\mathrm{BOD}_{5} / \mathrm{BOD}_{5,0}$ ratios was found to decrease linearly with $\mathrm{L}_{\mathrm{COD}}$ regardless of the initial $\mathrm{BOD}_{5,0}$ of leachate samples, with negative slopes of 0.40 and 0.38 , respectively. In summary, the Fenton process can be successfully used as a pre-treatment method to improve the biodegradability of mature leachates. Experimental results reported in this study demonstrate that the Fenton process increased the biodegradability of the mature leachate within a short reaction time from 1 to $5 \mathrm{~min}$. To increase biodegradability of a specific mature leachate at a given $\mathrm{BOD}_{5} / \mathrm{COD}$ target, Equations (7) and (8), developed in this study, can be used to predict the optimal amount of oxidant, $\mathrm{H}_{2} \mathrm{O}_{2}$, needed at either the lab-scale or pilot scale, to evaluate the Fenton process as a pre-treatment alternative before biological treatment.

Acknowledgments The authors are thankful to the Hinkley Center for Solid and Hazardous Waste Management at the University of Florida, Gainesville, for providing financial support to this research. Also, we like to thank Mr. Richard Urbina, Ms. Emma Lopez and Ms. Allison Vo in participating in the $\mathrm{BOD}_{5}$ measurements. A.G. Trovó is particularly indebted to CNPq (Conselho Nacional de Desenvolvimento Científico e Tecnológico - Brasil) for a scholarship (Process number: 240990/2012-9).

\section{References}

Batarseh ES, Reinhart DR, Daly L (2007) Liquid sodium ferrate and Fenton's reagent for treatment of mature landfill leachate. J Environ Eng 133:1042-1050

Clesceri LS, Greenberg AE, Eaton AD (2005) Standard methods for examination of water \& wastewater. American Public Health Association (APHA), American Water Works Association (AWWA) \& Water Environment Federation (WEF), Washington

Cortez S, Teixeira P, Oliveira R, Mota M (2011) Evaluation of Fenton and ozone-based advanced oxidation processes as mature landfill leachate pre-treatments. J Environ Manag 92:749-755

De Laat J, Gallard H (1999) Catalytic decomposition of hydrogen peroxide by Fe (III) in homogeneous aqueous solution: mechanism and kinetc modeling. Environ Sci Technol 33:2726-2732

de Morais JL, Zamora PP (2005) Use of advanced oxidation processes to improve the biodegradability of mature landfill leachates. J Hazard Mater 123:181-186

Deng Y, Englehardt JD (2006) Treatment of landfill leachate by the Fenton process: review. Water Res 40:3683-3694

EPA, Environmental Protection Agency (1988) Fed Regist 53(168):33345, August 30

Gernjak W, Fuerhacker M, Fernández-Ibañez P, Blanco J, Malato S (2003) Solar photo-treatment - process parameters and process control. Appl Catal B Environ 64:121-130

Goi A, Veressinina Y, Trapido M (2010) Fenton process for landfill leachate treatment: evaluation of biodegradability and toxicity. J Environ Eng 136:46-53

Gotvajn AZ, Zagorc-Koncan J, Cotman M (2011) Fenton's oxidative treatment of municipal landfill leachate as an alternative to biological process. Desalination 275:269-275 
Jiang C, Pang S, Ouyang F, Ma J, Jiang J (2010) A new insight into Fenton and Fenton-like processes for water treatment. J Hazard Mater 174:813-817

Lopez A, Pagano M, Volpe A, Di Pinto AC (2004) Fenton's pre-treatment of mature landfill leachate. Chemosphere 54:1005-1010

Machulek A Jr, Quina FH, Gozzi F, Silva VO, Friedrich LC, Moraes JEF (2012) Fundamental mechanistic studies of the photo-Fenton reaction for the degradation of organic pollutants: organic pollutants 10 years after the stockholm convention - environmental and analytical update. Rijeka, Croatia, pp 271-292

Melo SAS, Trovó AG, Bautitz IR, Nogueira RFP (2009) Degradation of residual pharmaceuticals by advanced oxidation processes. Quim Nova 32:188-197

Naumczysky J, Prokurat I, Marcinowski P (2012) Landfill leachates treatment by $\mathrm{H}_{2} \mathrm{O}_{2} / \mathrm{UV}, \mathrm{O}_{3} / \mathrm{H}_{2} \mathrm{O}_{2}$, modified Fenton, and modified photo-Fenton methods. Int J Photoenergy. doi:10.1155/2012/909157

Nogueira RFP, Guimarães JR (2000) Photodegradation of dichloroacetic acid and 2, 4-dichlorophenol by ferrioxalate $/ \mathrm{H}_{2} \mathrm{O}_{2}$ system. Water Res 34:895-901

Nogueira RFP, Trovó AG, da Silva MRA, Villa RD (2007) Fundamentals and environmental applications of Fenton and photo-Fenton processes. Quim Nova 30:400-408

Nurisepehr M, Jorfi S, Kalantary RR, Akbari H, Soltani RDC, Samaei M (2012) Sequencing treatment of landfill leachate using ammonia stripping, Fenton oxidation and biological treatment. Waste Manag Res 30:883-887

Papadopoulos AE, Fatta D, Loizidou M (2007) Development and optimization of dark Fenton oxidation for the treament of textile wastewaters with high organic load. J Hazard Mater 146:558-563

Pignatello JJ (1992) Dark and photoassisted $\mathrm{Fe}^{3+}$-catalyzed degradation of chlorophenoxy herbicides by hydrogen peroxide. Environ Sci Technol 26:944-951

Singh SK, Tang WZ (2013) Statistical analysis of optimum Fenton oxidation conditions for landfill leachate treatment. Waste Manag 33:81-88

Singh SK, Tang WZ, Tachiev G (2013) Fenton treatment of landfill leachate under different COD loading factors. Waste Manag 33:2116-2122

Tang WZ (2004) Physicochemical treatment of hazardous wastes. Lewis Publishers, Boca Raton

Tchobanoglous G, Theisen H, Vigil S (1993) Integrated solid waste management engineering principles and management issues. McGraw Hill, Boston

Trovó AG, Silva TFS, Gomes O Jr, Machado AEH, Borges Neto W, Muller PS Jr, Daniel D (2013) Degradation of caffeine by photo-Fenton process: optimization of treatment conditions using experimental design. Chemosphere 90:170-175

Umar M, Aziz HA, Yusoff MS (2010) Trends in the use of Fenton, electro-Fenton and photo-Fenton for the treatment of landfill leachate: review. Waste Manag 30:2113-2121

Vilar A, Eiroa M, Kennes C, Veiga MC (2013) Optimization of the landfill leachate treatment by the Fenton process. Water Environ J 27:120-126

Wang F, Smith DW, El-Din MG (2003) Application of advanced oxidation methods for landfill leachate treatment - a review. J Environ Eng Sci 2:413-427

Wu T, Englehardt JD (2012) A new method for removal of hydrogen peroxide interference in the analysis of chemical oxygen demand. Environ Sci Technol 46:2291-2298

Zhang H, Choi H, Huang CP (2005) Optimization of Fenton process for the treatment of landfill leachate. J Hazard Mater 125:166-174 